\title{
Aspectos geológicos e pedológicos dos solos do município de Montes Claros - MG
}

\author{
Regynaldo Arruda Sampaio ${ }^{1}$, Luiz Arnaldo Fernandes ${ }^{2 *}$ \\ DOI: https://doi.org/10.35699/2447-6218.2021.33964
}

\begin{abstract}
Resumo
Objetivou-se realizar o levantamento dos aspectos geológicos e pedológicos bem como interpretações sobre fertilidade dos solos do município de Montes Claros - MG. O levantamento foi realizado a partir de dados de literatura, de incursões a campo para verificação de informações, de descrição de perfil de solo e de resultados de análises químicas e físicas de solo. Ao final foram sistematizadas recomendações gerais de uso e manejo para as principais ordens de solo do município, com destaque para a calagem, fertilização com nitrogênio e fósforo, e adoção de práticas de incremento da matéria orgânica e de conservação do solo.
\end{abstract}

Palavras chave: Levantamento de solo. Capacidade de uso das terras. Classificação de solo.

\section{Geological and pedological aspects of soils in the municipality of Montes Claros - MG}

\begin{abstract}
The objective was to carry out a survey of the geological and pedological aspects as well as interpretations on soil fertility in the municipality of Montes Claros - MG. The survey was carried out using literature data, field incursions to verify information, description of the soil profile and results of soil chemical and physical analysis. At the end, general recommendations for use and management were systematized for the main soil orders in the municipality, with emphasis on liming, fertilization with nitrogen and phosphorus, and adoption of practices to increase organic matter and soil conservation.
\end{abstract}

Key words: Soil survey. Land use capability. Soil classification.

${ }^{1}$ Universidade Federal de Minas Gerais. Montes Claros, MG. Brasil. https://orcid.org/0000-0003-3214-6111

${ }^{2}$ Universidade Federal de Minas Gerais. Montes Claros, MG. Brasil. https://orcid.org/0000-0002-9877-1924

*Autor para correspondência: luizmcmg@gmail.com

Recebido para publicação em 07 de maio de 2021. Aceito para publicação em 17 de maio de 2021 e-ISSN: 2447-6218 / ISSN: 2447-6218. Atribuição CC BY. 


\section{Introdução}

O solo é um componente fundamental do ecossistema terrestre e representa a interface entre os diversos compartimentos que influenciam diretamente a vida humana, como a litosfera, hidrosfera, atmosfera e biosfera. Na agricultura tem papel relevante como substrato e fonte de água, nutrientes e ar para as plantas, bem como, na regulação dos processos de infiltração, armazenamento e escoamento da água. A sua conservação e manejo adequados geram riquezas, proporcionando de forma sustentável a necessária produção de matéria-prima que alimenta a indústria e a economia regional (Lepsch, 2011; Rezende et al., 2014).

Neste contexto, realizou-se o levantamento dos aspectos geológicos e pedológicos, e de fertilidade dos solos, do município de Montes Claros - MG.

\section{Material e Métodos}

Para o levantamento dos aspectos geológicos e pedológicos utilizou-se de informações disponíveis em Jacomine et al. (1979), Chaves e Benitez (2007), Valadão et al. (2008), UFV - CETEC - UFLA - FEAM (2010), Chaves e Andrade (2012); IBGE (2012), Chaves e Andrade (2014a), Chaves e Andrade (2014b), Kuchenbecker e Costa (2014), Kuchenbecker et al. (2014) e Embrapa (2018), de incursões a campo para verificação de informações e de descrição de perfis de solo.

A partir dos dados de literatura e dos trabalhos de campo foi apresentada a coluna estratigráfica, foi sistematizada uma evolução geológica e petrográfica das unidades estratigráficas do Cráton São Francisco, foram construídos e, ou adaptados mapas de geologia, de altitude, de vegetação e de solos e, foi esquematizada uma seção, na latitude $16^{\circ} 44^{\prime} 0^{\prime \prime}$ 'S (porção central do município, na direção leste-oeste), com informações de geologia, de geomorfologia, de pedologia e de vegetação do município de Montes Claros.

Os aspectos relacionados à fertilidade do solo foram levantados a parir de análises químicas e físicas de amostras de solo e de incursões a campo para levantamento da fertilidade natural do solo, friabilidade, rochosidade, declividade, profundidade efetiva (horizontes $\mathrm{A}+\mathrm{B})$, susceptibilidade à erosão e limitações ao uso agrícola (médio e alto nível tecnológico) das principais ordens de solo do município de Montes Claros - MG. A partir desses resultados foram propostas algumas recomendações gerais de uso e manejo das principais ordens de solo do município de Montes Claros - MG.

\section{Resultados e Discussão}

\section{Contexto geológico}

O município de Montes Claros encontra-se sobre as unidades litoestratigráficas do Grupo Bambuí e de coberturas fanerozóicas (Figuras 1, 2 e 3).

Os limites geográficos dessas unidades litoestratigráficas situam-se entre a Serra do Espinhaço, a leste, e o Rio São Francisco, a oeste, encontrando-se inserida na zona de transição entre o Cráton São Francisco e a Faixa de Dobramentos Araçuaí. O Cráton mencionado é formado por uma plataforma cristalina surgida em tempos pré-brasilianos e que serviu de antepaís para as faixas de dobramentos firmadas no Brasiliano. Por situar-se externamente ao cinturão orogênico, as estruturas sedimentares sofreram pouco metamorfismo (Chaves et al., 2011; Chaves e Andrade, 2014a).

A formação geológica de maior extensão exposta à superfície no município é a Lagoa do Jacaré, a qual se subdivide nas fácies Calcários e Metassiltitos Rítmicos (Figura 4), ocupando o sudoeste e a faixa central do munícipio na direção norte-sul. O calcário é maciço, puro e de cor cinza-escuro, com predominância de calcilutitos e calcarenitos, enquanto os ritmitos apresentam alternâncias de níveis milimétricos argilo-siltosos de coloração cinza-clara, com níveis carbonáticos de coloração cinza-escura. A formação com calcário caracteriza-se pela melhor qualidade dos substratos em relação a fertilidade do solo, principalmente de cálcio. Todavia, esse litotipo tende a ocupar faixas de relevos mais acidentados e com menor aptidão agrícola (Figura 5).

A Formação Serra de Santa Helena, formada de metassiltitos, tende a formar solos de baixa fertilidade (Figura 4). Porém, possui uma boa concentração de muscovita, o que pode explicar os teores variando de médio a alto de potássio nos solos dessa formação. Embora constitua uma faixa de relevo de altitude mais baixa, com condições hídricas mais favoráveis (Figura 5), as limitações edáficas contribuem para o estabelecimento de vegetação de Cerrado e de Floresta Estacional (Figura 6).

A Formação Serra da Saudade, formada de argilitos, siltitos e diamictitos, tende também a ter solos menos férteis (Figura 4), embora possua boa concentração de muscovita, com boa disponibilidade de potássio (Figuras 1 e 3). Neste ambiente, encontram-se os solos mais desenvolvidos, como os Latossolos (Figura 7), e pela condição hídrica mais limitada, a vegetação de Cerrado ou contato Cerrado / Floresta Estacional (Figura 4). 
Figura 1 - Coluna estratigráfica do município de Montes Claros - MG. As espessuras das unidades não se encontram em escala real. Fonte: Adaptado de Chaves e Andrade (2014a).

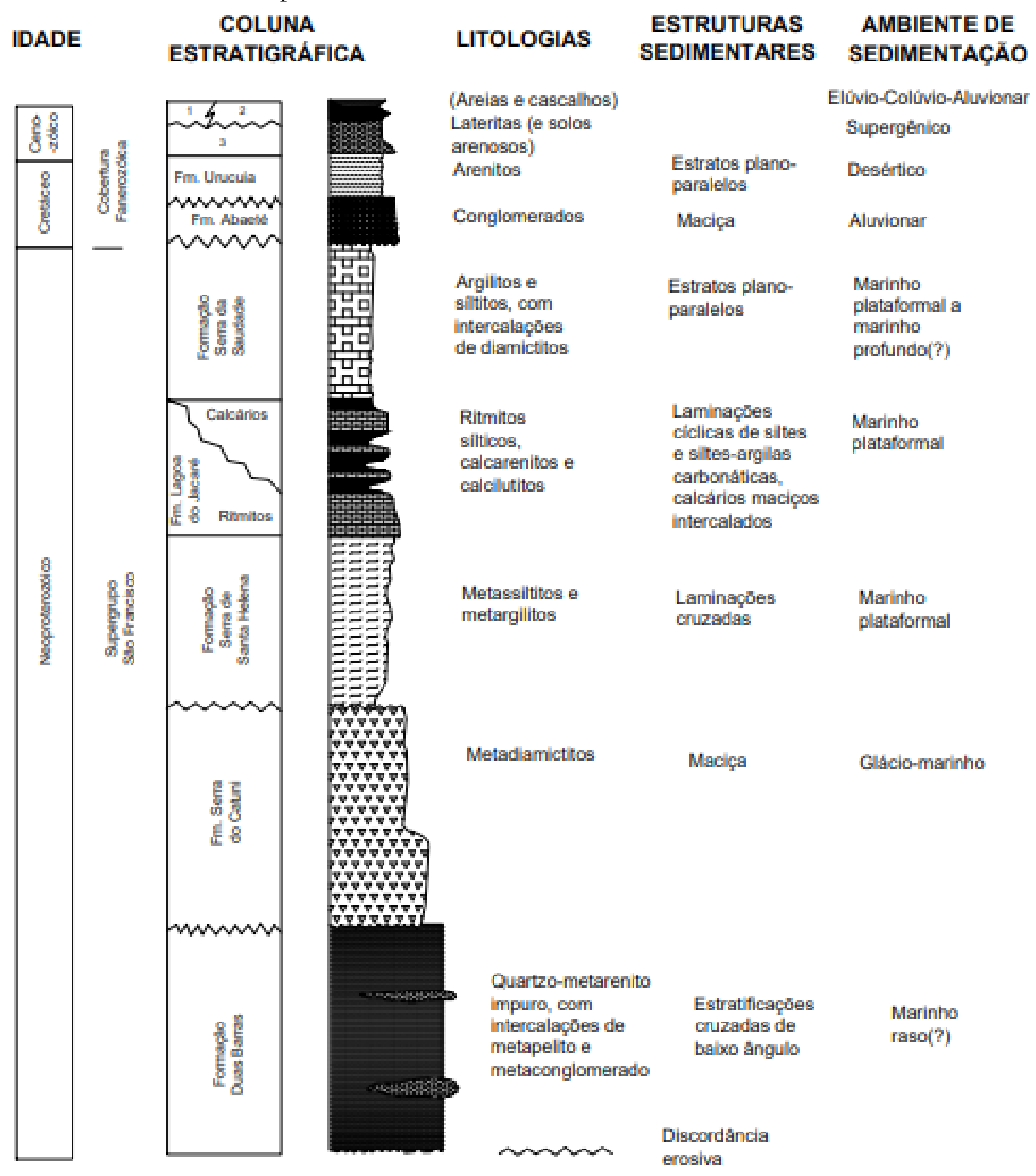

NOTAS:

1- Aluvibes.

2- Dep. Colluvio-Eluviais.

3 - Dep. Detrinco-Leteriticos.

Os Depósitos Elúvio-Coluvionares compreendem uma boa extensão da faixa ocidental do município de Montes Claros, aflorando em manchas restritas, cobrindo e tendo adjacência principalmente a formação Serra da Saudade e Lagoa do Jacaré (Figura 4). São constituídos por sedimentos areno-siltosos, de cores amareladas à avermelhadas, contendo fragmentos de quartzo de veio esparsos, e presença de superfícies lateritizadas em alguns locais. Os solos desse ambiente são mais intemperizados e também com maior restrição hídrica, sendo a área ocupada por vegetação de Cerrado em contato com a Floresta Estacional (Figura 6).

Os Depósitos detrítico-lateríticos abrangem uma boa parte da porção norte/nordeste do município (Figura

4). Nestes substratos são encontradas coberturas arenosas finas a médias, consolidadas ou semiconsolidadas, sendo em geral de coloração vermelha intensa, indicando contribuição ferruginosa. É uma área de grande ocorrência de Nitossolos (Figura 7), sendo um ambiente de mais baixa altitude (Figura 5) e de maior conservação de umidade. A vegetação característica deste ambiente é a Floresta Estacional-Caducifólia (Figura 6).

A Formação Urucuia distribui-se de forma esparsa do centro ao sul do município e é constituída por arenitos finos, com intercalações locais de siltitos (Figura 4). Os arenitos são predominantes, possuindo cores variando de branca a branca-avermelhada, enquanto os arenitos siltosos e siltitos apresentam coloração roxa. Esta for- 
Sampaio, R. A.; Fernandes, L. A.

mação encontra-se em altitude mais elevada (Figura 5), sendo os solos desse ambiente o Latossolo, o Cambissolo e o Neossolo (Figura 7). Pelas restrições hídricas e baixa fertilidade dos solos, a área é principalmente de ocorrência de vegetação de Cerrado (Figura 6).

Figura 2 - Evolução geológica e petrografia das unidades estratigráficas 1, 2, 34 e 5 do Cráton São Francisco.

\begin{tabular}{|c|c|}
\hline Evolução geológica ${ }^{(1)}$ & Petrografia $^{(1)}$ \\
\hline $\begin{array}{l}1 \text { - Deposição dos sedimentos arenosos da Formação Duas Barras, } \\
\text { basal do Grupo Macaúbas, em ambiente marinho raso a fluvial, numa } \\
\text { idade inferior a aproximadamente } 900 \text { milhões de anos, cobrindo os } \\
\text { sedimentos siliciclásticos mesoproterozóicos do Supergrupo Espinha- } \\
\text { ço (que ocorrem a sul e leste, fora da área), principal abastecedor de } \\
\text { material clástico dessa formação. }\end{array}$ & $\begin{array}{l}\text { Formação Duas Barras: Quartzo-metarenitos } \\
\text { impuros formados à base de quartzo ( } 85- \\
94 \%) \text {, fragmentos de rochas (0-10\%), óxidos } \\
\text { e argilominerais (5-6\%). Presença de musco- } \\
\text { vita, rutilo e limonita dispersos na estrutura } \\
\text { da rocha. }\end{array}$ \\
\hline $\begin{array}{l}2 \text { - A Formação Duas Barras é sobreposta pelos diamictitos de am- } \\
\text { biente glacial da Formação Serra do Catuni. Embora na área esses } \\
\text { sedimentos estejam mal expostos, e ainda bastante mascarados pela } \\
\text { deformação, a sul eles foram caracterizados como de origem glacio- } \\
\text { marinha proximal. A idade máxima de sedimentação para tais depó- } \\
\text { sitos é balizada em cerca de } 850 \text { milhões de anos. }\end{array}$ & $\begin{array}{l}\text { Formação Serra do Catuni: Metadiamictitos } \\
\text { formados de argilominerais (4-80\%), quart- } \\
\text { zo }(15-65 \%) \text {, carbonatos e óxidos }(0-5 \%) \text {, } \\
\text { sericita }(0-1 \%) \text {, fragmentos de rochas (0- } \\
30 \%) \text {. Presença de biotita dispersa na estru- } \\
\text { tura da rocha. }\end{array}$ \\
\hline $\begin{array}{l}3 \text { - É possível que tenha ocorrido um hiato sedimentar expressivo, } \\
\text { até iniciar a sedimentação pelito-carbonática do Grupo Bambuí. Esses } \\
\text { depósitos foram acumulados em um mar epicontinental preferencial- } \\
\text { mente raso, com certas porções localizadas mais profundas, numa } \\
\text { bacia de antepaís (foreland), onde a principal área-fonte de detritos } \\
\text { estaria a oeste, na região da Faixa Brasília. }\end{array}$ & - \\
\hline $\begin{array}{l}4 \text { - A seção basal do Grupo Bambuí, Formação Sete Lagoas (não pre- } \\
\text { sente no município de Montes Claros), foi datada em } 740 \text { milhões } \\
\text { de anos, que indicam os quase } 100 \text { milhões (máximos) de anos de } \\
\text { diferença para a sequência inferior, cujos calcários representam típi- } \\
\text { cos Cap carbonates. Nesta etapa, pode ter havido um expressivo hiato } \\
\text { deposicional dentro da própria sequência. }\end{array}$ & - \\
\hline $\begin{array}{l}5 \text { - A sedimentação das formações Serra de Santa Helena e Lagoa do } \\
\text { Jacaré na área enfocada, marca regionalmente o segundo megaciclo } \\
\text { deposicional da Bacia Bambuí, o qual se caracteriza por uma sequên- } \\
\text { cia basal marinha transgressiva (Formação Serra de Santa Helena) } \\
\text { que evolui para outra, regressiva (Formação Lagoa do Jacaré), com } \\
\text { seus depósitos típicos de mar bastante raso. }\end{array}$ & $\begin{array}{l}\text { Formação Serra de Santa Helena: Metassil- } \\
\text { titos formados de quartzo }(50 \%) \text {, argilomi- } \\
\text { nerais }(30 \%) \text {, muscovita }(10 \%) \text { e óxidos de } \\
\text { ferro }(10 \%) \text {. } \\
\text { Formação Lagoa do Jacaré (Metassiltitos } \\
\text { Rítmicos): Base síltica com argilominerais } \\
(92-94 \%) \text {, quartzo ( } 2-5 \%) \text {, óxidos (1-2\%) e } \\
\text { muscovita (1-2\%). } \\
\text { Formação Lagoa do Jacaré (Calcários): Cal- } \\
\text { cilutitos e calcarenitos com } 95-98 \% \text { de car- } \\
\text { bonato e } 2-5 \% \text { de argilominerais, sulfetos } \\
\text { (pirita) e quartzo. }\end{array}$ \\
\hline
\end{tabular}

A Formação Abaeté, pertencente ao grupo Areado, distribui-se de forma esparsa na porção meio norte e noroeste do município (Figura 4). Essa unidade é formada de conglomerados clasto-sustentados, polimíticos, com seixos de quartzitos, quartzo e metapelito, com ocorrência em condições de maior altitude (Figura 5). O Latossolo é a ordem predominante deste ambiente (Figura 7), sendo ocupado pela vegetação de Cerrado (Figura 6).

Os Depósitos aluvionares constituem a menor e a mais recente unidade geológica, situada na porção norte do município sobre a Formação Serra de Santa Helena (Figura 4). Os depósitos têm ocorrência nas áreas de mais baixas altitudes do município (Figura 5) e são formados de sedimentos arenosos com cascalhos inconsolidados, com ampla presença de seixos de quartzo arredondados e por sedimentos de silte e argila. Solos como os Neossolos e Argissolos são encontrados neste ambiente (Figura 7), bem como a predominância de Floresta estacional-caducifólia (Figura 6).

\section{Distribuição e atributos das principais ordens de solos} do município

A área total do município de Montes Claros é de $3.576,76 \mathrm{~km}^{2}$, sendo as ordens de solos, conforme o 
Sistema Brasileiro de Classificação de Solos (Embrapa, 2018), na escala de 1:100.000, distribuídas da seguinte forma: Nitossolo Háplico $\left(1.623,49 \mathrm{~km}^{2}\right)$, Latossolo Vermelho-Amarelo $\left(780,45 \mathrm{~km}^{2}\right)$, Cambissolo Háplico $\left(437,08 \mathrm{~km}^{2}\right)$, Neossolo Litólico (382,00 km²), Argissolo Vermelho-Amarelo $\left(227,48 \mathrm{~km}^{2}\right)$ e Latossolo Vermelho $\left(126,26 \mathrm{~km}^{2}\right.$ ) (Figura 7).

Figura 3 - Evolução geológica e petrografia das unidades estratigráficas 6, 7, 8 e 9 do Cráton São Francisco.

\begin{tabular}{|c|c|}
\hline Evolução geológica $^{1}$ & Petrografia $^{1}$ \\
\hline $\begin{array}{l}6 \text { - O terceiro megaciclo de sedimentação do Grupo Bambuí é ca- } \\
\text { racterizado na região pela sedimentação dos argilitos e diamictitos } \\
\text { da Formação Serra da Saudade, os quais evidenciam uma nova fase } \\
\text { transgressiva, cujos depósitos possuem localmente evidências de mar } \\
\text { mais profundo. Neste período, a sedimentação que vai caracterizar } \\
\text { uma nova regressão marinha, representada pelos depósitos arenosos } \\
\text { da Formação Três Marias, não ocorre na região (somente a oeste), } \\
\text { constituindo o topo do Grupo Bambuí. }\end{array}$ & $\begin{array}{l}\text { Formação Serra da Saudade: Rocha pelítica } \\
\text { formada por argilominerais (25-60\%), mus- } \\
\text { covita (10-30\%), quartzo (15-30\%) e óxidos } \\
\text { (5-10\%). }\end{array}$ \\
\hline $\begin{array}{l}7 \text { - A sedimentação da Bacia Bambuí ocorreu em parte paralelamente } \\
\text { à edificação das faixas Brasília (a oeste) e Araçuaí (a leste) às mar- } \\
\text { gens do Cráton São Francisco, durante a orogenia Brasiliana. Esse } \\
\text { período orogênico teve seu clímax desenvolvido entre } 630 \text { e } 490 \\
\text { milhões de anos, promovendo dobramentos e falhamentos na zona } \\
\text { externa ao cráton, afetando ainda as unidades inferiores do Grupo } \\
\text { Bambuí, principalmente nas áreas próximas às margens cratônicas. }\end{array}$ & \\
\hline
\end{tabular}

8 - Um longo período de quiescência tectônica sobreveio ao final do Formação Abaeté: Conglomerados clastoBrasiliano. A geração da Bacia Sanfranciscana, termo utilizado para designar a depressão na qual se acumularam as coberturas fanerozóicas sobre o Cráton São Francisco, iniciou-se no final do Paleozóico, possuindo representantes na área enfocada com os depósitos continentais fluviais e eólicos, respectivamente, possuindo idades cretácicas inferior (Formação Abaeté) e superior (Formação Urucuia).

-sustentados, polimíticos, com seixos de quartzitos (predominantes), quartzo e metapelito, com quase ausência de matriz e um cimento silicoso, depositados em sistemas fluviais e de leques aluviais.

Formação Urucuia: Formada por arenitos finos, vermelhos, de sedimentação eólica, compostos de quartzo (60-95\%), argilominerais (2-20\%), óxidos (1-20\%) e fragmentos de rochas (0-2\%). Presença de muscovita dispersa na estrutura da rocha.

9 - No final, essas unidades cretácicas de cobertura do cráton são soerguidas e capeadas, durante o Cenozóico, por sedimentos inconsolidados, representados por depósitos detrítico-lateríticos, colúvio-eluviais e aluvionares.
Depósitos detrítico-lateríticos: Coberturas arenosas finas a médias, consolidadas ou semi-consolidadas, em geral de coloração vermelha intensa denotando contribuição ferruginosa, com formação em diversos locais de horizontes lateríticos.

Depósitos colúvio-eluviais: Sedimentos areno-siltosos amarelos a avermelhados, contendo fragmentos de quartzo de veio esparsos, com ocorrência restrita de superfícies laterizadas.

Depósitos aluvionares: Sedimentos arenosos com cascalhos inconsolidados, com amplo predomínio de seixos de quartzo arredondados, e também por sedimentos enriquecidos por silte e argila.

(1) Adaptado de Chaves et al. (2011) e Chaves e Andrade (2014a).

A ordem Nitossolo Háplico é a que ocupa maior área no município (45,39\% da área total), apresentando, em geral, como principais atributos, o Horizonte A de textura argilosa ou muito argilosa, com estrutura do tipo blocos, de tamanho médio, consistência seca, moderada ou forte e consistência úmida firme, com transição gradual 
Sampaio, R. A.; Fernandes, L. A.

e plana entre horizontes. O horizonte $\mathrm{B}$ nítico é de textura argilosa ou muito argilosa, com estrutura prismática ou em blocos, de tamanho médio e grau moderado ou forte, e consistência muito dura, friável, muito plástica e muito pegajosa, com cerosidade comum e forte, e transição di- fusa e plana. São solos com profundidade dos horizontes $\mathrm{A}+\mathrm{B}$ maiores do que $100 \mathrm{~cm}$, apresentando matiz da amostra úmida e seca de 5,0YR e 7,5YR, respectivamente, e relação silte/argila menor do que 0,7 .

Figura 4 - Mapa geológico do município de Montes Claros. Adaptado de Chaves e Benitez (2007); Chaves e Andrade (2012); Chaves e Andrade (2014a); Chaves e Andrade (2014b); Kuchenbecker e Costa (2014); Kuchenbecker et al. (2014).

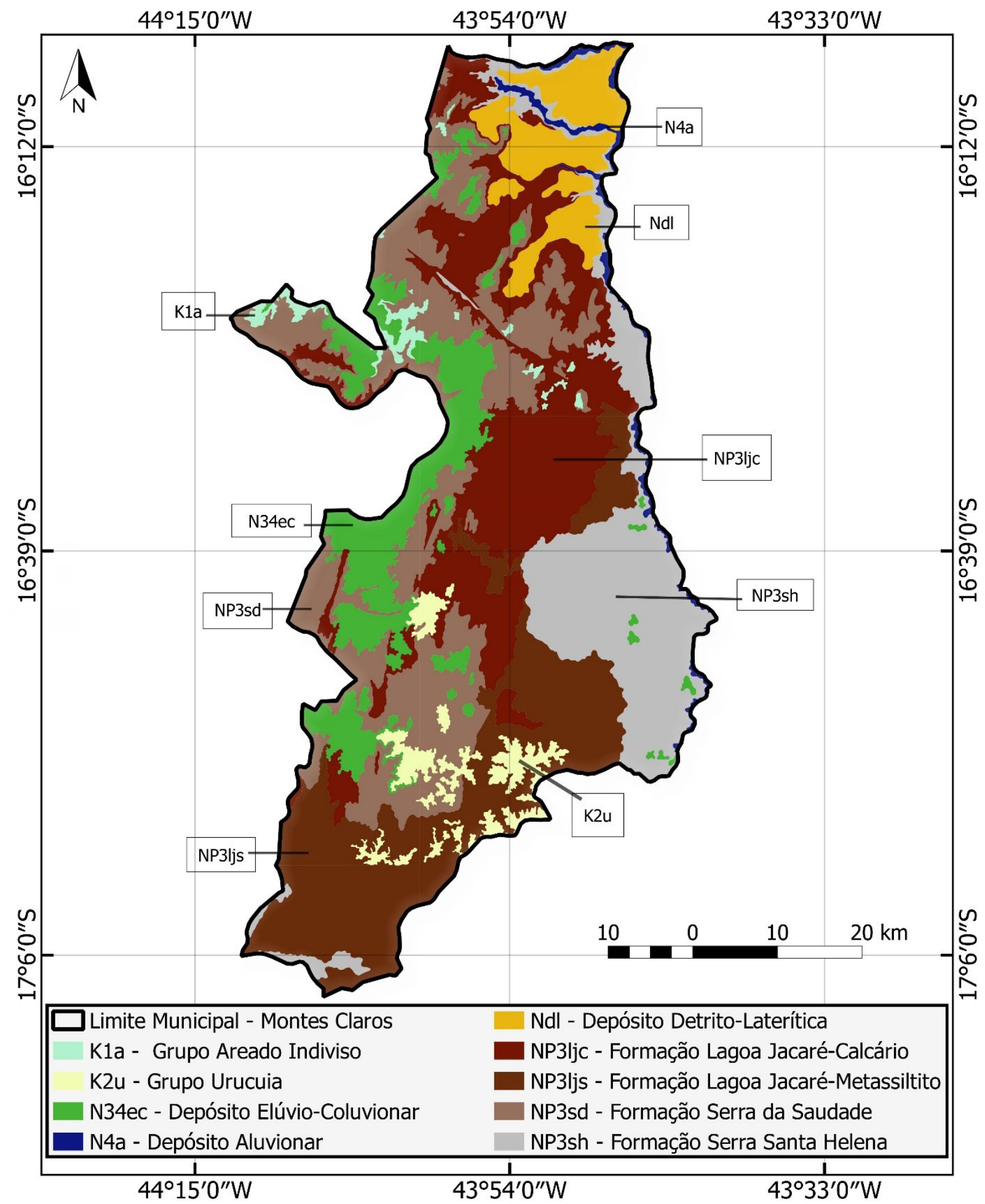

Em condição de escala mais detalhada, observa-se na área de ocorrência de Nitossolos Háplicos, em situações onde há maior concentração de ferro, a presença também do Nitossolo Vermelho, com matiz 10 R, ou, onde existem 
Aspectos geológicos e pedológicos dos solos do município de Montes Claros - MG

cores policromáticas, encontra-se Argissolos, os quais são classificados assim apenas por não atenderem ao critério de ausência de policromia, mesmo não apresentando gradiente textural ou mudança textural abrupta.

Os Nitossolos Háplicos concentram-se na faixa central e leste do município, em altitudes mais baixas, em relevos planos a suave ondulados, com declives de até $8 \%$, com boa profundidade e boa aptidão agrícola. Contudo, são solos cauliníticos, com baixa CTC, dis- tróficos, ácidos, com índice de saturação por alumínio acima de 50\%, necessitando da aplicação de corretivos de acidez e adubação para o cultivo de plantas. Quando derivados de rochas calcárias, apresentam $\mathrm{pH}$ neutro, alta saturação por bases e baixa saturação por alumínio. Do ponto de vista físico, são solos com taxas de infiltração de água não muito elevadas e baixa capacidade de água disponível, com susceptibilidade a erosão laminar, sendo indispensável em seu manejo agrícola, o incremento de matéria orgânica.

Figura 5 - Mapa de altitude do município de Montes Claros. Adaptado de Chaves e Andrade (2014a).

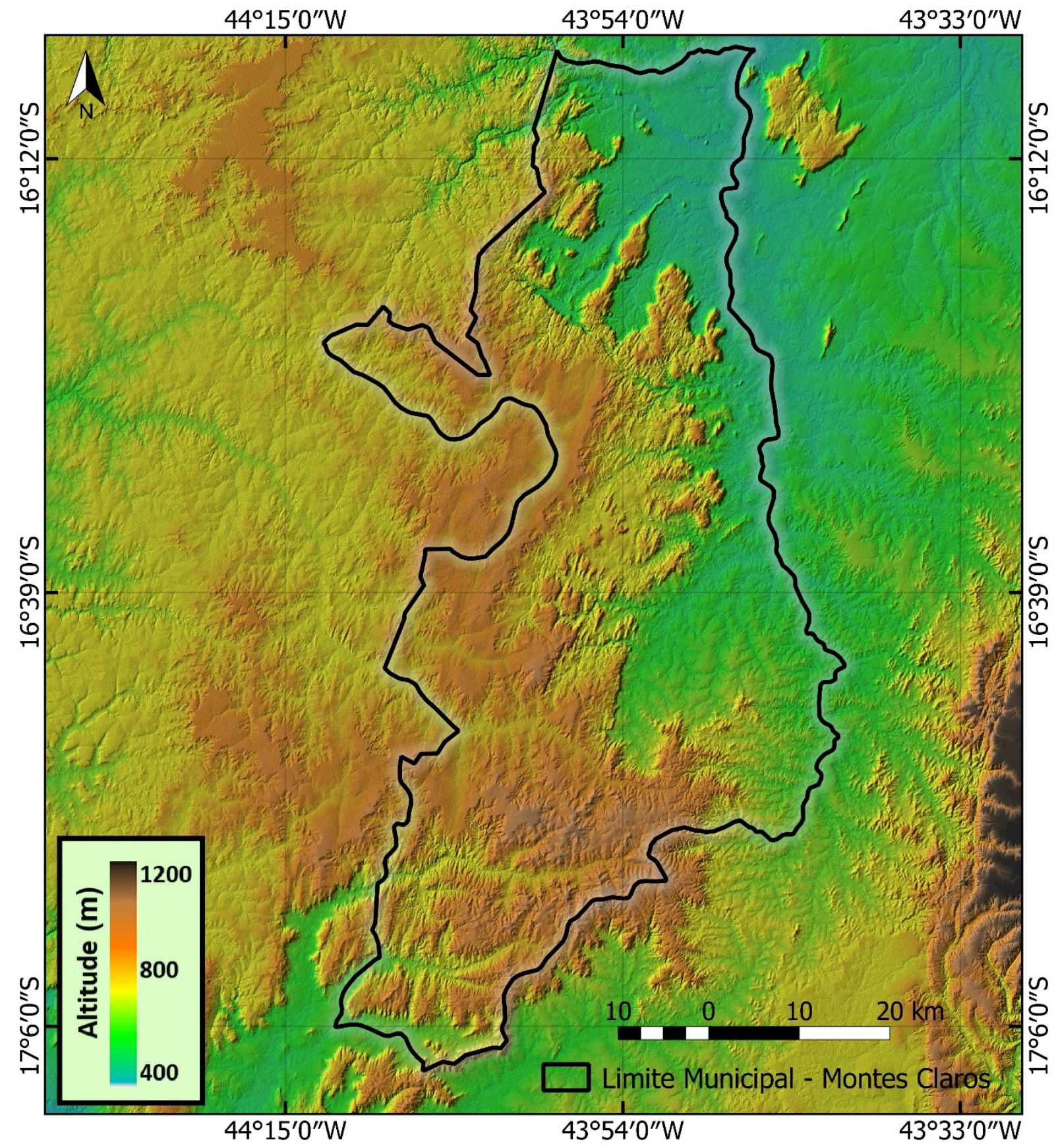

O Latossolo Vermelho-Amarelo é a segunda ordem de maior ocorrência no município de Montes Claros (21,82\% da área total), situando-se na região oeste da localidade e tendo como atributos gerais, o Horizonte A de textura média, na forma de grãos simples, com consistência da amostra úmida e seca do tipo solta, e consistência molhada do tipo não plástica e não pegajosa, com transição gradual e plana. O Horizonte B latossólico é de textura média, na forma de grãos simples, com consistência similar ao Horizonte A e transição difusa e 
Sampaio, R. A.; Fernandes, L. A.

plana entre horizontes. São solos com profundidade dos horizontes $\mathrm{A}+\mathrm{B}$ maiores do que $200 \mathrm{~cm}$, apresentando matiz da amostra úmida e seca de 5,0 a 7,5 YR, respectivamente, e relação silte/argila menor do que 0,7 .

Figura 6 - Mapa de vegetação do município de Montes Claros. As pequenas variações de vegetação locais não estão representadas no mapa em razão da escala pouca detalhada. Adaptado de IBGE (2012).

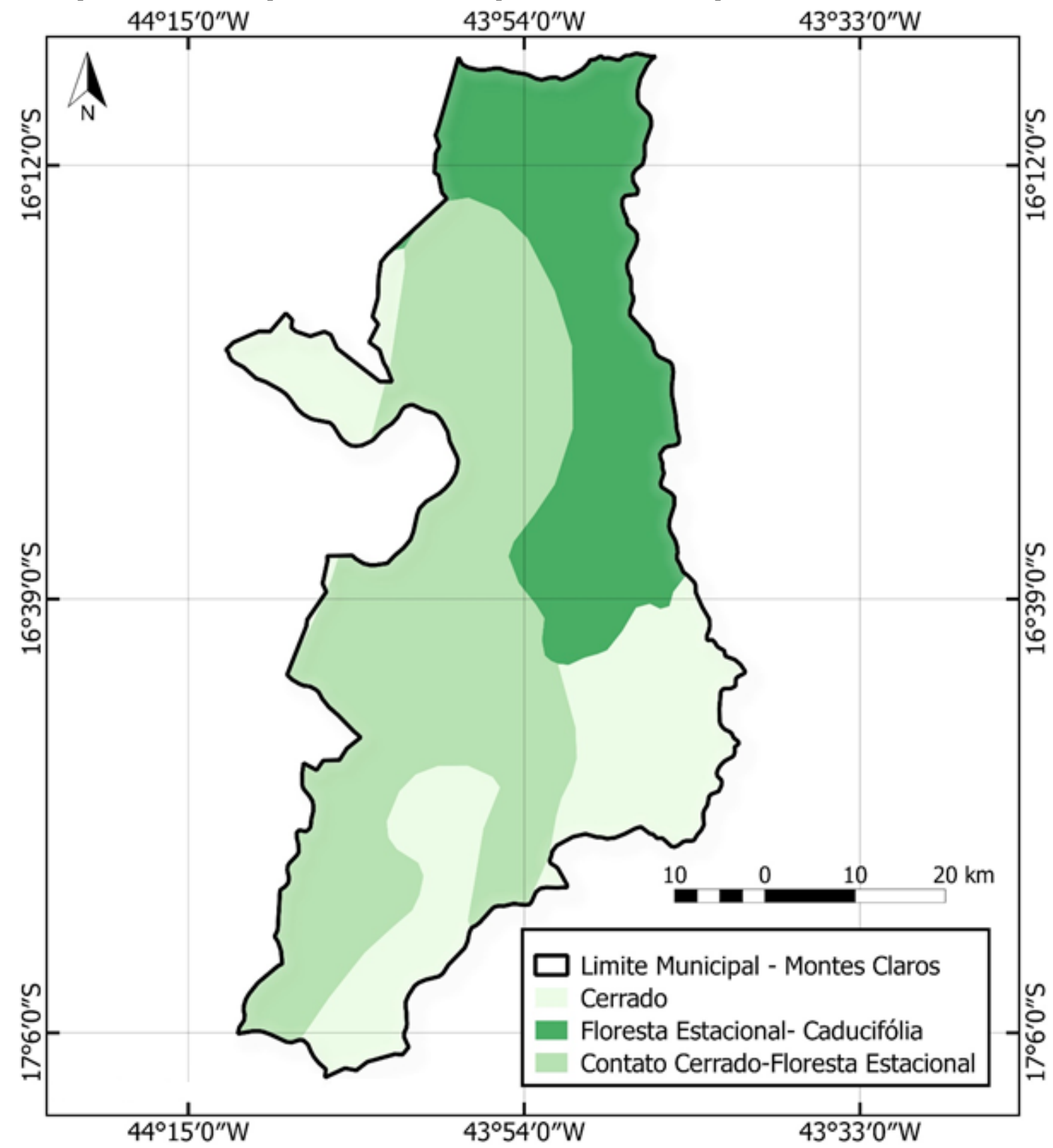

Na área de ocorrência desse solo, verifica-se em condição de maior detalhamento da escala, a associação com Neossolo Quartzarênico, o qual apresenta ausência de Horizonte B e textura arenosa até pelo menos $150 \mathrm{~cm}$ de profundidade ou até o contato lítico.

Os Latossolos Vermelho-Amarelos na região situam-se em relevos planos a suave ondulados, com declives de até $8 \%$, com boa profundidade e boa aptidão agrícola. Contudo, são solos muito pobres em ferro, com predominância de caulinita, com CTC extremamente baixa, distróficos, ácidos, necessitando da aplicação de corretivos de acidez, bem como, de adubação para o cultivo de plantas. Do ponto de vista físico, são solos com taxas de infiltração de água não muito elevadas, em razão da elevada percentagem de areia fina ( $\cong 50 \mathrm{dag} \mathrm{kg}^{-1}$ ), e baixa capacidade de retenção e de água disponível, com susceptibilidade a erosão laminar, sendo indispensável em seu manejo agrícola, o incremento de matéria orgânica. É um solo com limitações agrícolas muito mais pronunciadas do que a ordem Nitossolo Háplico antes descrita.

O Cambissolo Háplico é a terceira ordem de solos de maior ocorrência no município $(12,22 \%$ da 
área total), concentrando-se mais na área centro-sul e sudeste da localidade. Como atributos gerais desta ordem verifica-se Horizonte A com textura argila-siltosa, com estrutura maciça e consistência da amostra seca e úmida dura e friável, respectivamente, e consistência da amostra molhada plástica e pegajosa, apresentando ainda transição clara e plana. O Horizonte B incipiente é de textura argilo-siltosa, do tipo blocos pequenos e médios e grau fraco, com consistência da amostra seca e úmida dura e muito friável, respectivamente, e consistência molhada plástica e pegajosa, com transição gradual e plana, com matiz da amostra úmida e seca variando de 5YR a 10YR, e relação silte/argila superior a 0,7.

Figura 7 - Mapa de solos do município de Montes Claros (Adaptado de UFV - CETEC - UFLA - FEAM, 2010).

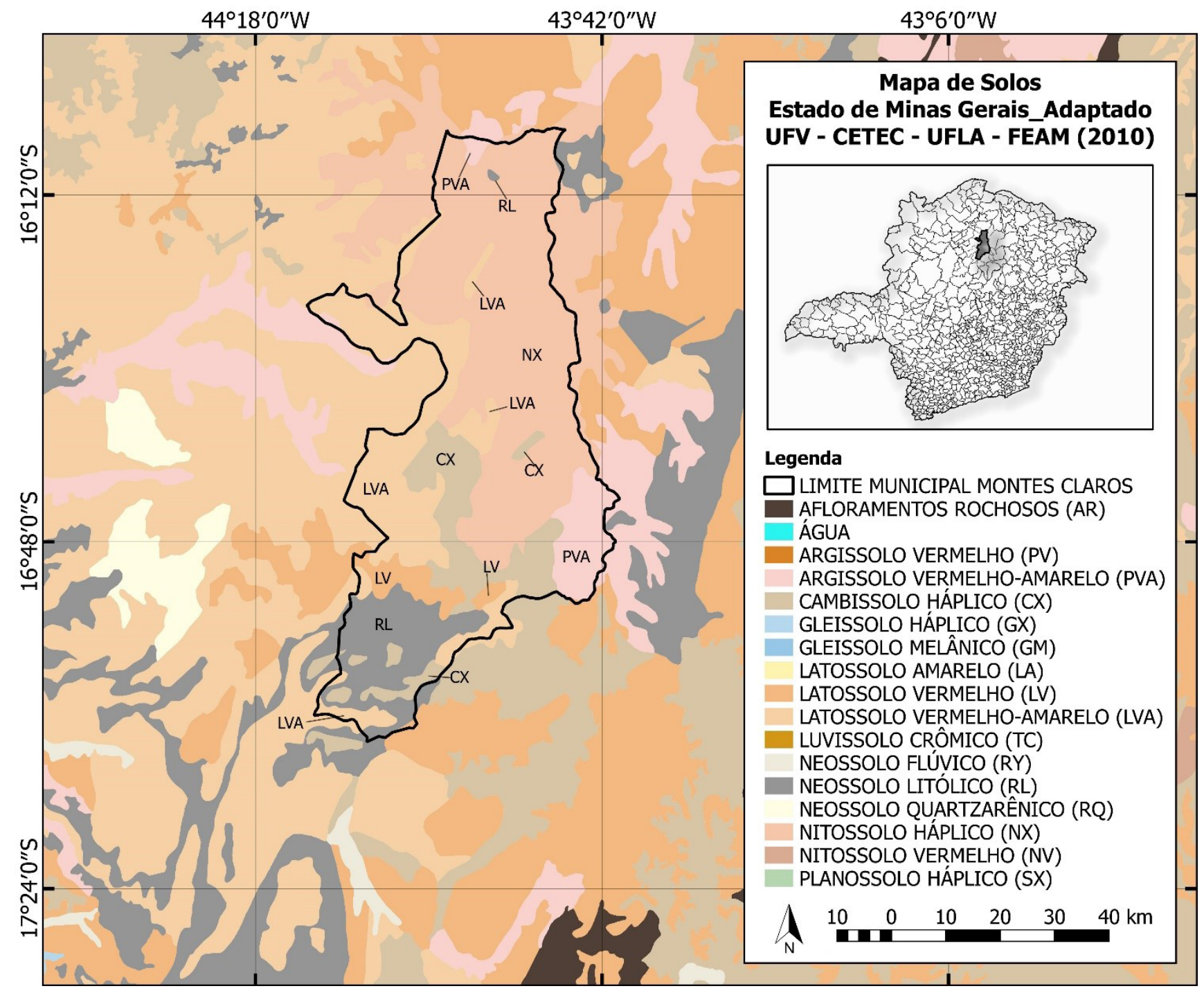

Os Cambissolos Háplicos no município situam-se em relevo ondulado e forte ondulado, com declives entre 8 e 45\%, não muito profundos, apresentando algumas restrições ao uso agrícola. Quando mal manejados e expostos a erosão, tendem a apresentar exposição de "toá". São solos predominantemente cauliníticos, ácidos, com baixa CTC e baixa saturação por bases, e índice de saturação por alumínio elevado, necessitando da aplicação de corretivos de acidez, bem como, de adubação para o uso agrícola. Todavia, quando sob influência de Formação Lagoa do Jacaré (calcário), tem pH básico e alta saturação de bases, com boa fertilidade. Do ponto de vista físico, são solos com taxas de infiltração de água baixos, principalmente em razão do alto teor de silte, e, tanto pela declividade quanto pela baixa infiltração de água, são solos muito susceptíveis a erosão. Requerem para o seu uso agrícola a adoção de práticas intensivas de conservação do solo e da água.

Os Neossolos Litólicos ocupam 10,68\% da área total do município de Montes Claros, situando-se na área sudoeste da localidade, em área de relevo ondulado a montanhoso, com declives entre 20 e 45\%. Apresentam contato lítico ou lítico fragmentário numa profundidade de até $50 \mathrm{~cm}$, apresentando horizonte A assentado diretamente sobre a rocha ou sobre um horizonte $\mathrm{C}$ ou Cr ou sobre material com $90 \%$ ou mais, por volume, de sua massa constituída por fragmentos grosseiros, como cascalhos, calhaus e matacões. 
Sampaio, R. A.; Fernandes, L. A.

Quando formados por influência do calcário, o Horizonte A é de textura franco-argilosa, com estrutura granular de tamanho pequeno a muito pequeno, grau moderado, e consistência da amostra seca e úmida ligeiramente dura e muito friável, respectivamente, e consistência molhada plástica e pegajosa, com transição abrupta e plana. São solos cauliníticos, com $\mathrm{pH}$ próximo a neutralidade, sem alumínio trocável, com alta percentagem de saturação de bases, relação silte/argila próxima de 1 e cores de amostras de solos secas e úmidas variando de 5 YR a 10YR.

Por outro lado, quando formados a partir de ardósia e metargilito, apresentam textura franco argilo-siltosa, com estrutura em blocos de tamanho pequeno e médio, e grau moderado, com consistência seca e úmida ligeiramente dura e friável, respectivamente, e consistência molhada muito plástica e muito pegajosa, com transição clara e plana. São solos cauliníticos, com pH acima de 5,5, com índice de saturação de alumínio muito baixo, com percentagem de saturação de bases acima de $50 \%$, relação silte/argila acima de 1,5 e cores de amostras de solos secas e úmidas com matiz variando de 5YR a 10YR. Apesar da boa fertilidade, são solos rasos, pouco desenvolvidos e muito erosivos, prestando-se somente para uso como área de reserva ambiental.

Os Argissolos Vermelhos-Amarelos ocupam 6,36\% da área total do município, situando-se principalmente na porção sudeste da localidade, em relevo suave ondulado a forte ondulado, com declividades variando de 3 a 45\%. São solos que apresentam, em geral, Horizonte A com textura franco-argilosa ou argilosa, estrutura granular ou em blocos de tamanho variando de pequeno a médio, com grau moderado e consistência da amostra seca e úmida dura e firme, e consistência molhada muito plástica e muito pegajosa; com transição clara e plana. $\mathrm{O}$ Horizonte B tem textura muito argilosa, com estrutura do tipo blocos de tamanho médio e grau moderado, e cerosidade abundante e moderada, com consistência da amostra seca e úmida dura e firme, e consistência da amostra molhada plástica e muito pegajosa, e relação silte/argila inferior a 0,7 . As cores dos horizontes variam de 7,5 a 2,5YR, o que confere a estes solos a presença de policromia, sendo esse fato determinante para a sua diferenciação dos Nitossolos, uma vez que pode apresentar gradiente textural insuficiente para atender ao critério de classificação do horizonte diagnóstico como B textural.

São solos cauliníticos, ácidos, com baixa CTC, baixa saturação de bases e alto índice de saturação de alumínio, necessitando da aplicação de corretivos de acidez, bem como, de adubação para o cultivo. Do ponto de vista físico, são solos com taxas de infiltração de água não muito elevadas e baixa capacidade de água disponível, com susceptibilidade a erosão laminar, sendo indispensável em seu manejo agrícola, o incremento de matéria orgânica e práticas de conservação do solo.
Os Latossolos Vermelhos ocupam 3,53\% da área total do município, situando-se na porção sudoeste da localidade, em relevos planos a suave ondulados, com declives de até $8 \%$. De modo geral, apresenta como principais atributos, o Horizonte A de textura média, na forma de grãos simples, com consistência da amostra seca e úmida do tipo macia e muito friável, e consistência molhada do tipo ligeiramente plástica e ligeiramente pegajosa, com transição gradual e plana. O Horizonte B latossólico é de textura média, na forma granular, com consistência similar ao Horizonte A e transição difusa e plana entre horizontes. São solos com profundidade dos horizontes $A+B$ maiores do que $200 \mathrm{~cm}$, apresentando matiz da amostra úmida e seca de 2,5YR ou mais vermelho, e relação silte/argila menor do que 0,7.

Os Latossolos Vermelhos possuem uma concentração um pouco mais elevada de ferro e situam-se em relevos planos a suave ondulados, com declives de até $8 \%$, com boa profundidade e boa aptidão agrícola. Contudo, são solos com predominância de caulinitas, com CTC baixa, distróficos, ácidos, necessitando da aplicação de corretivos de acidez, bem como, de adubação para o cultivo de plantas. Em algumas áreas sob influência de calcário no material de origem, apresentam boa fertilidade natural. Do ponto de vista físico, são solos com boas taxas de infiltração de água, todavia, com baixa capacidade de retenção e de água disponível, com susceptibilidade a erosão laminar ligeira, sendo indispensável em seu manejo agrícola, o incremento de matéria orgânica.

Convém ressaltar que outras ordens de solos são constatadas no município, porém, de forma muito localizadas, como os Gleissolos e Vertissolos nas proximidades de rios e lagos, bem como, de Plintossolos em ambientes mal drenados e com segregação de ferro. Em substrato calcário, onde há maior acúmulo de matéria orgânica e teores elevados de bases trocáveis, e de carbonatos, nota-se a presença de horizonte A Chernozêmico e, consequentemente, de Chernossolos. Em algumas depressões podem ocorrer teores mais elevados de sódio (percentagem de sódio trocável igual ou maior do que 15\%), causando dispersão de argilas e impermeabilização do solo quando as concentrações de sais na solução do solo são baixas (condutividade elétrica do extrato de saturação do solo menor do que $4 \mathrm{dS} \mathrm{m}^{-1}$ ).

Considerando as variações topográficas dentro da formação geológica Serra de Santa Helena, a qual é formada por metassiltitos com folhelhos ardosianos intercalados, verifica-se a sequência de evolução de solos apresentada na Figura 8. Destaca-se, neste caso, a formação de um saprolito sobre a rocha, o qual é menos denso do que a rocha original e com cores amareladas e vermelho-amareladas, denotando perdas e reações de oxidação do ferro, apresentando ainda um pouco de porosidade. Esses fragmentos, quando expostos na superfície por erosão da camada de solo superficial, recebe a denominação popular de "toá" (Matos, 2008), sendo considerado pelos agricultores como um indicativo de área 
Aspectos geológicos e pedológicos dos solos do município de Montes Claros - MG

inadequada para a prática agrícola e bastante vulnerável. "O "toá" é um termo regional, possivelmente derivado da palavra tauá (taguá), que significa barro na língua Tupi-Guarani. O tauá quando umedecido pode ser utilizado, por exemplo, para pintar casas (taba). Combinada com a palavra "tinga" (cor branca), tauá-tinga, ambas do Tupi-Guarani, podem ter originado a palavra "Tabatinga" (barro branco) (Bueno, 1987, citado por Resende et al., 2014).

Em ambientes de substrato calcário (Formação Lagoa do Jacaré), pode ocorrer nos horizontes mais profundos a presença de nódulos ferromanganosos do tipo "chumbinho de caça", que estão associados aos carbonatos de cálcio. Esses nódulos são indicadores de alterações no regime hídrico dos solos, com alternância de condições de alagamento (redução) e de déficit hídrico (oxidação), o que permite a movimentação e precipitação de ferro e manganês no solo (Oliveira et al., 2001).

Conforme já comentado, os solos desse ambiente calcário apresentam boa fertilidade (Figura 9). Contudo, o relevo mais movimentado requer sempre a adoção de práticas de conservação dos solos, para evitar as perdas por erosão. Quando bem manejados, com curvas de nível, cordões de retenção, terraços, adição de matéria orgânica, preparo do solo e sistema de cultivo adequados, permanecerão como um meio de produção agrícola valioso e proveitoso.

Figura 8 - Sequência de material de origem e de solos da Formação Serra de Santa Helena: Metassiltito (A); Saprolito do Metassiltito - "toá" (B); Superfície do solo erodida com exposição de "toá" (C); Neossolo Litólico (D); Cambissolo Háplico (E) e Nitossolo Háplico (F).
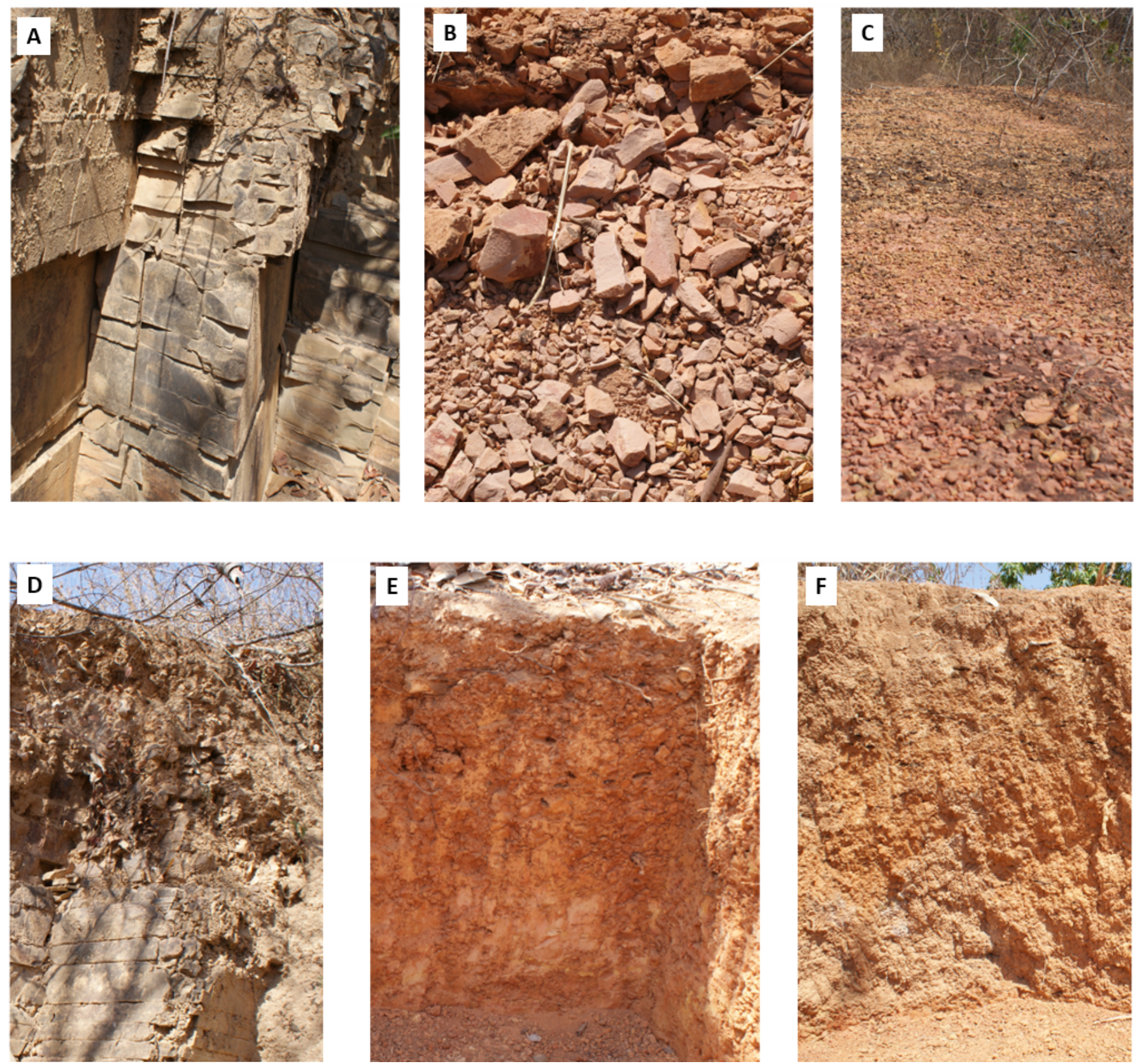
Sampaio, R. A.; Fernandes, L. A.

Na condição de relevo de mais baixa altitude, típico de Floresta Estacional-Caducifólia (Figura 10), ocorrem as melhores condições hídricas para a atividade agrícola. Condição essa que se sobrepõe a da fertilidade do solo, uma vez que se trata de um município com baixo índice pluviométrico e má distribuição de chuvas. Neste contexto, as práticas de conservação de água e solo já mencionadas devem ser estimuladas, a fim de tornar esse ambiente ainda mais conservador de umidade.

Figura 9 - Detalhes de um Neossolo Litólico com exposição de rocha calcária (A) e de um Cambissolo Háplico (B) na Formação Lagoa do Jacaré (Calcários).
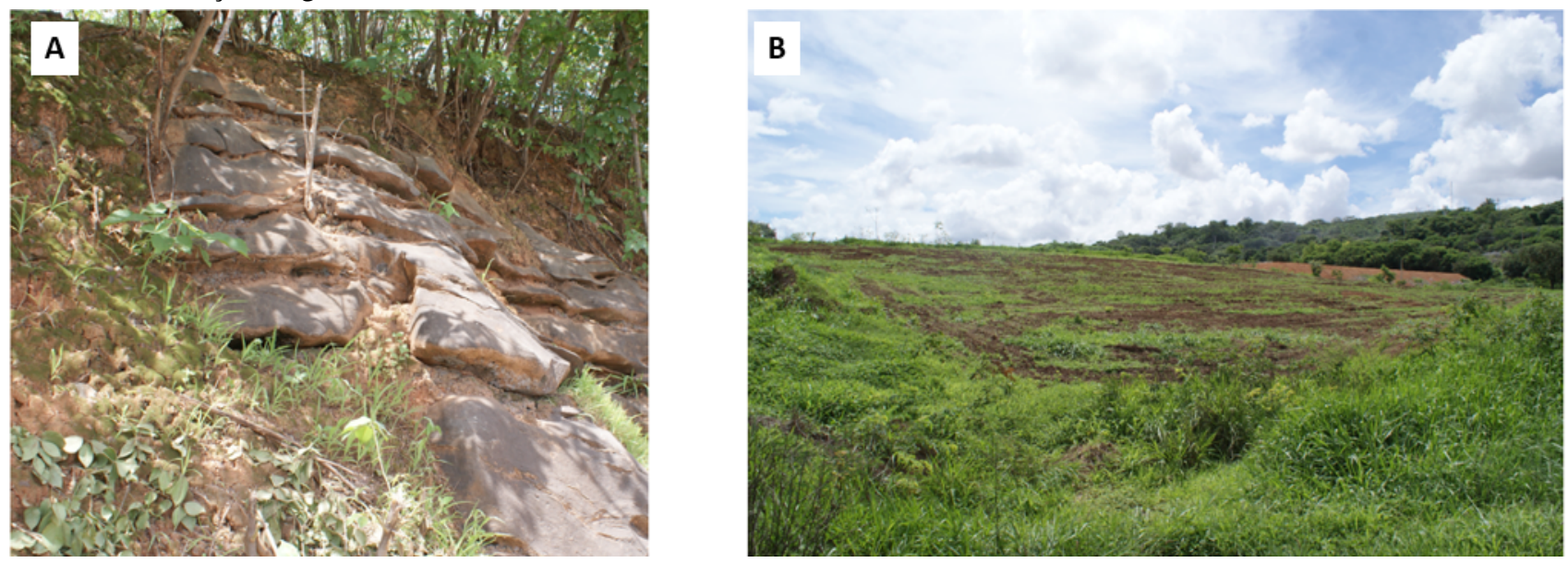

Figura 10 - Seção geológica, geomorfológica, pedológica e de vegetação do município de Montes Claros na latitude $16^{\circ} 44^{\prime} 0$ "S (porção central, direção leste-oeste).
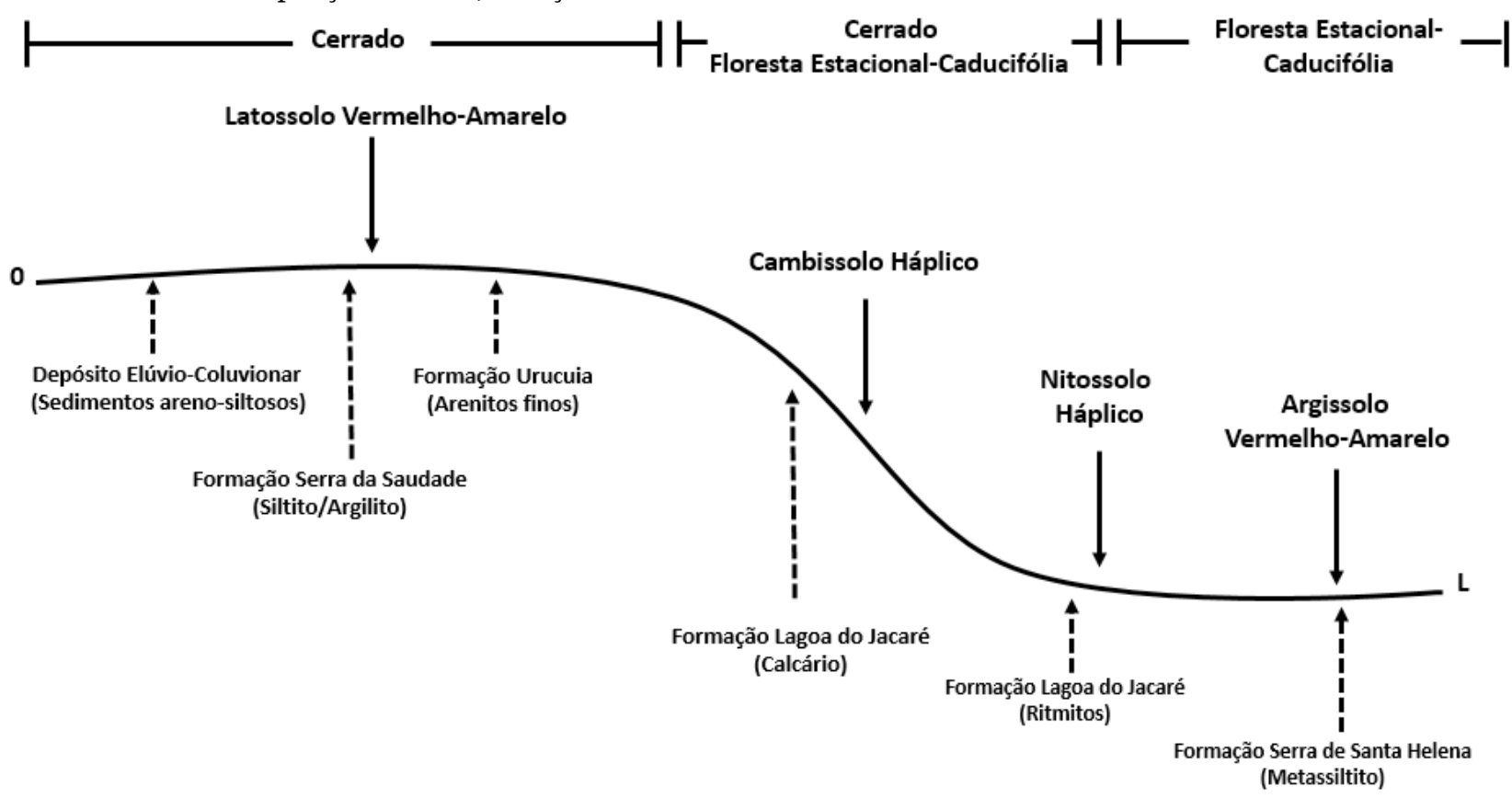

\section{Fertilidade e Uso Agrícola dos Solos}

Na Tabela 1 são apresentados os valores de alguns atributos físicos e químicos de amostras de solo coletadas na camada superficial ( 0 a $20 \mathrm{~cm}$ de profundidade), em áreas de vegetação nativa / não cultivada, das principais ordens de solo que ocorrem no município de Montes Claros. Todavia, recomenda-se, para fins de manejo da fertilidade do solo e de irrigação, uma amostragem mais detalhada da área a ser manejada, em função da variabilidade espacial dos atributos do solo e da escala utilizada nesse trabalho.
De modo geral, os solos do município de Montes Claros apresentam baixa fertilidade natural, exceto algumas manchas (pequenas áreas) de influência de rochas calcárias. Nas áreas de Latossolo Vermelho-Amarelo, Latossolo Vermelho e Argissolo Vermelho-Amarelo, o pH, os teores de nutrientes (cálcio, magnésio, potássio e fósforo) e os valores de saturação por bases e capacidade de troca de cátions (CTC) variam de muito baixos a baixos, enquanto que os valores de alumínio (acidez trocável) são elevados, exceto no Latossolo Vermelho-Amarelo, que varia de baixo a médio (Tabela 1). 
Aspectos geológicos e pedológicos dos solos do município de Montes Claros - MG

Tabela 1 - Atributos químicos e físicos do solo (média \pm desvio padrão) de amostras coletadas na camada superficial (0 a $20 \mathrm{~cm}$ de profundidade) em áreas de vegetação nativa / não cultivada. Análises químicas realizadas de acordo com as metodologias descritas em Ribeiro et al. (1999) e físicas, de acordo com Teixeira et al. (2017).

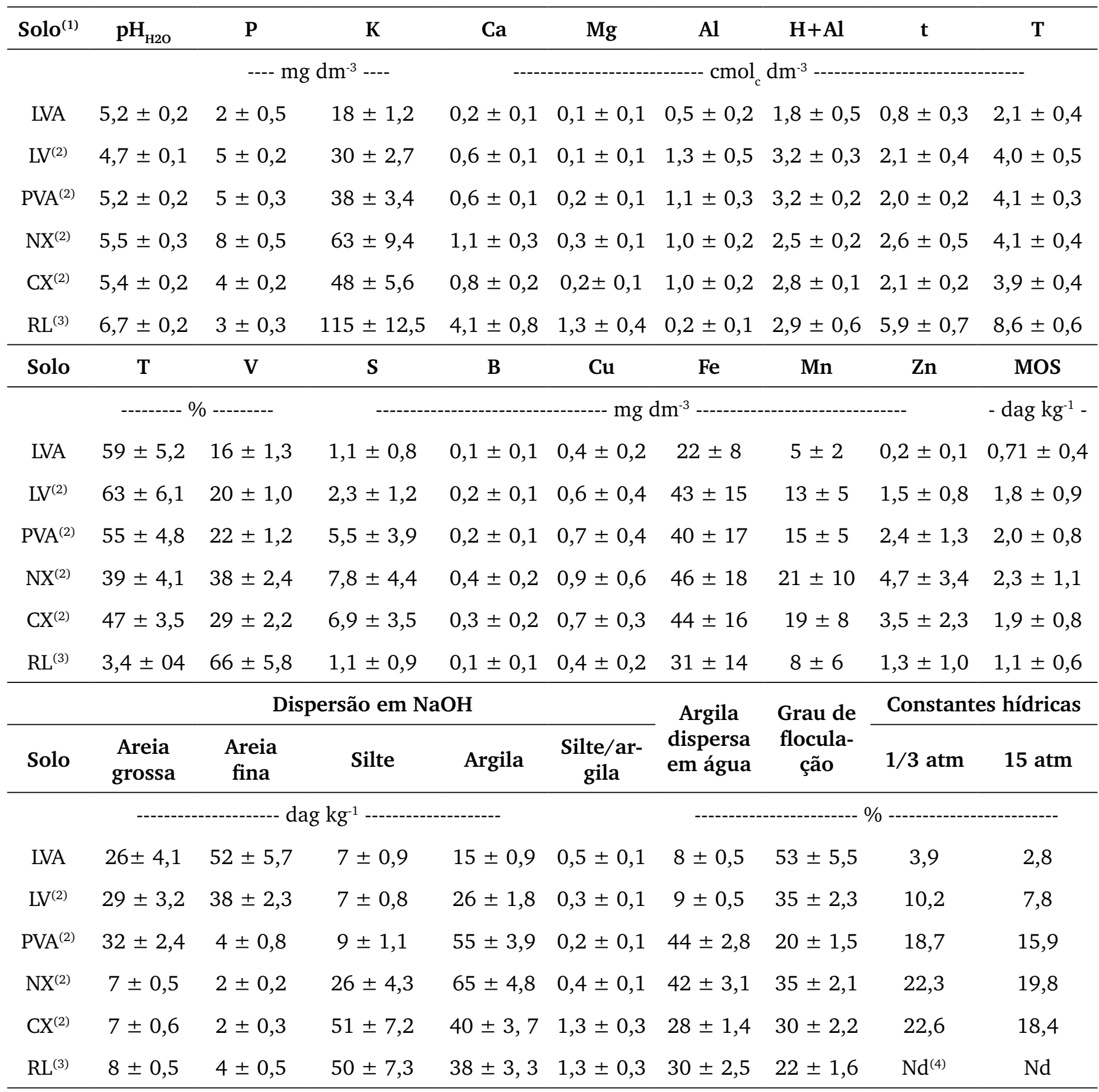

(1) LVA: Latossolo Vermelho-Amarelo; LV: Latossolo Vermelho; PVA: Argissolo Vermelho-Amarelo; NX: Nitossolo Háplico; CX: Cambissolo Háplico; RL: Neossolo Litólico. (2) Algumas manchas de LV, PVA, NX e CX apresentam valores mais elevados de pH e de Ca+Mg quando desenvolvidos a partir de rochas calcárias. Em algumas machas desses solos, principalmente de PVA, os teores de K são elevados, em função da ocorrência de muscovita no material de origem. Algumas manchas de NX apresentam teores médios a altos de P. (3) Apesar de apresentarem acidez fraca ou neutra e elevada saturação por bases, os teores de P são baixos. (4) Não determinado.

Em algumas manchas de Latossolo Vermelho a CTC pode alcançar valores elevados em função dos altos teores de matéria orgânica do solo e, ou, de saturação por bases, como naqueles originados e, ou, de influência de rochas calcárias. Da mesma forma, podem ocorrer manchas de Argissolo Vermelho-Amarelo com teores médios a elevados de potássio em função do material de origem, por exemplo, presença de muscovita.
Nas áreas de ocorrência de Nitossolo Háplico e Cambissolo Háplico os solos apresentam baixos teores de fósforo, cálcio e magnésio, enquanto que os de potássio variam de baixos a médios (Tabela 1 ). Os valores de alumínio (acidez trocável) são elevados e os valores de pH, de saturação por bases e de CTC são baixos. Nessas áreas ocorrem manchas de solo com teores mais elevados de cálcio, magnésio, potássio e CTC, e baixos teores de 
Sampaio, R. A.; Fernandes, L. A.

alumínio trocável. Principalmente nas áreas de Nitossolo Háplico ocorrem manchas com teores de fósforo mais elevados, quando comparados aos encontrados nos demais solos do município, que variam de muito baixos a baixos.

Os Neossolos Litólicos, tantos os formados a partir de rochas calcárias quanto àqueles formados a partir de ardósias e metargilitos / metassiltitos, apresentam teores elevados de cálcio, magnésio e potássio, e alta CTC, bem como, muito baixos teores de alumínio trocável e de fósforo disponível (Tabela 1). No entanto, os teores de cálcio, magnésio e potássio dos Neossolos Litólicos originados de ardósias e metargilitos / metassiltitos, são ligeiramente menores do que aqueles encontrados nos Neossolos Litólicos originados de rochas calcárias. Além disso, os Neossolos Litólicos originados de ardósias e metargilitos / metassiltitos apresentam teores mais elevados de alumínio trocável. Os valores de CTC elevados se devem principalmente aos altos teores de cálcio e magnésio, uma vez que, a CTC potencial (T) é estimada pela soma das bases trocáveis $\left(\mathrm{Ca}^{+2}, \mathrm{Mg}^{+2}\right.$ e $\left.\mathrm{K}^{+}\right)$e acidez potencial $\left(\mathrm{H}^{+}+\mathrm{Al}^{+3}\right)$.

Os teores de enxofre e micronutrientes variam de baixo a alto, sendo os valores mais elevados encontrados nos solos Nitossolo Háplico, Argissolo Vermelho-Amarelo e Cambissolo Háplico (Tabela 1). Já os teores de matéria orgânica do solo variam de muito baixo a médio (Tabela 1), provavelmente devido às condições climáticas da região, como, por exemplo, elevadas temperaturas ao longo do ano, que favorecem o processo mineralização pelos microrganismos do solo. Verificou-se uma grande variabilidade espacial dos solos em relação a esses atributos, reforçando a necessidade de amostragens mais detalhadas da área a ser manejada / cultivada.

Do ponto de vista do manejo da fertilidade do solo para fins de cultivos agrícolas para a obtenção de médias a altas produtividades, há a necessidade de correção da acidez do solo e de adubações, uma vez que, no município de Montes Claros, a maioria dos solos são ácidos e o fósforo é o nutriente que se encontra em menor disponibilidade para as plantas. A baixa fertilidade dos solos do município pode ser superada com o emprego de tecnologias adequadas, não sendo, portanto, por si só, restritiva à agricultura. Nas áreas de ocorrência de solos eutróficos ( $\mathrm{V}>50 \%$ ), originados ou de influência de rochas calcárias, há uma grande resposta das culturas à adubação fosfatada.

Duarte et al. (2015) verificaram ganhos significativos de produtividade de lavouras de milho cultivadas em Latossolo Vermelho eutrófico e Nitossolo Háplico eutrófico do município de Montes Claros. O termo eutrófico, usado para designar solos de alta fertilidade, refere-se à proporção de cátions básicos trocáveis $\left(\mathrm{Ca}^{+2}, \mathrm{Mg}^{+2} \mathrm{e}\right.$ $\mathrm{K}^{+}$) em relação à CTC potencial. De acordo com esse conceito, solos com alta saturação por bases (V > 50\%) são denominados eutróficos. No trabalho de Duarte et al.
(2015), os elevados valores de saturação por bases dos solos foram devidos aos teores alto e muito alto de cálcio e potássio, respectivamente. Por outo lado os tores de magnésio eram baixos, contribuindo para elevadas relações $\mathrm{Ca} / \mathrm{Mg}$. Nessa situação, dependendo das exigências nutricionais das culturas, há a necessidade de adubação com magnésio.

Apesar das limitações de fertilidade do solo serem relativamente fáceis de serem corrigidas, os fatores climáticos e físicos podem ser limitantes ao uso agrícola mais intensivo das terras. Por exemplo, a seca prolongada, a pouca profundidade efetiva (horizontes $\mathrm{A}+\mathrm{B}$ ), a ocorrência de afloramentos rochosos e, ou elevada declividade do terreno são os fatores mais limitantes ao uso agrícola das terras do município. Na região Norte de Minas, o período chuvoso concentra-se nos meses de outubro a março, com alta probabilidade de veranicos. Clima do município, de acordo com a classificação de Köppen, é do tipo Aw (tropical com inverno seco) (Alvares et al., 2013). Dessa forma, o uso agrícola das terras sem irrigação apresenta limitações moderadas a fortes devido ao período de seca prolongado e, ou, ocorrência de veranicos. Os Latossolos Vermelho-Amarelo e Neossolos Quartzarênicos, comuns nas Chapadas do Norte de Minas, por serem mais arenosos, apresentam, teoricamente, em anos normais de precipitação pluviométrica, menor disponibilidade de água para as plantas nos horizontes superficiais - seca edafológica (Fernandes et al., 2008). Regionalmente é denominada por Chapada a porção mais elevada da paisagem, com relevo plano a suave ondulado, solos arenosos e vegetação de Cerrado típico.

Em relação à irrigação, águas de poços tubulares que exploram aquíferos cársticos apresentam valores elevados de condutividade elétrica, de cálcio, e de carbonatos e bicarbonatos, entre outros, que podem comprometer a produtividade das culturas. $\mathrm{O}$ excesso de cálcio e de carbonatos livres contribuem para elevar o $\mathrm{pH}$ do solo, diminuir a disponibilidade de micronutrientes (boro, zinco, cobre, ferro, manganês) e de fósforo, desequilibrar as relações entre nutrientes, principalmente cálcio / magnésio / potássio, favorecer perdas de nitrogênio e alterar o metabolismo das plantas, entre outras consequências. Mesmo em solos ácidos, com poucos ciclos de cultivos irrigados com águas calcárias o pH atinge valores próximos ou acima de 7,0.

Nas manchas de Nitossolo Háplico e Cambissolo Háplico, e nos Neossolos Litólicos, que apresentam naturalmente valores mais elevados de saturação por bases e de $\mathrm{pH}$ (próximos a neutralidade), é comum diagnosticar plantas com sintomas visuais de deficiências nutricionais causadas pela baixa disponibilidade de micronutrientes, como boro, zinco, cobre, manganês e ferro, principalmente no período seco.

Uma das alternativas para reduzir o $\mathrm{pH}$ dos solos alcalinos é a utilização do fertilizante sulfato de amônio $\left.\left(\mathrm{NH}_{4}\right)_{2} \mathrm{SO}_{4}\right)$ nas adubações nitrogenadas. Valadares et al. 
Aspectos geológicos e pedológicos dos solos do município de Montes Claros - MG

(2014), trabalhando com um Cambissolo Háplico eutrófico do município de Montes Claros, conseguiram reduzir o pH de 7,2 para 5,6 com a aplicação de $120 \mathrm{~kg} \mathrm{ha}^{-1}$ de nitrogênio na forma de sulfato de amônio na cultura do milho. De acordo com os autores, essa redução de $\mathrm{pH}$ foi devida as reações do processo de nitrificação, que geram acidez, ou seja, acidificam o solo. Nesse processo, o amônio $\left(\mathrm{NH}_{4}^{+}\right)$é transformado em nitrato (NO3-) por microrganismos quimioautotróficos presentes no solo, conforme a seguinte reação simplificada: $\left(\mathrm{NH}_{4}\right)_{2} \mathrm{SO}_{4}+$ $4 \mathrm{O}_{2} \rightarrow 2 \mathrm{NO}_{3^{-}}+\mathrm{SO}_{4}^{-2}+2 \mathrm{HOH}+4 \mathrm{H}^{+}$.

É importante ressaltar que solos com altos valores de $\mathrm{pH}$, condutividade elétrica e sódio trocável são de difícil manejo. No entanto, nos solos do município de Montes Claros os teores de sódio são muito baixos, exceto em alguns pontos muito localizados da paisagem, principalmente em depressões do terreno, em que o sódio pode estar em concentrações mais elevadas. Em relação a condutividade elétrica e a salinidade, mudas de algumas espécies nativas do Cerrado, como pequi (Caryocar brasiliense Camb), na fase de viveiro, têm se mostrado muito sensíveis a irrigação com águas de poços tubulares e até mesmo com águas tratadas. Como exemplo, a água de poço tubular utilizada para a irrigação da área do trabalho de Valadares et al. (2014), apresentava: $\mathrm{pH}=$ 7,8; condutividade elétrica $=1,84 \mathrm{dS} \mathrm{m}^{-1} ; \mathrm{Ca}^{+2}=15,3$ mmol L${ }^{-1} ; \mathrm{Mg}^{+2}=5,6 \mathrm{mmol} \mathrm{L}^{-1} ; \mathrm{Na}^{+}=33,1 \mathrm{mmol} \mathrm{L}^{-1}$; $\mathrm{Cl}-=5,2 \mathrm{mmol} \mathrm{L}^{-1} ; \mathrm{HCO}_{3^{-}}=19,0 \mathrm{mmol} \mathrm{L}^{-1} \mathrm{e}$; razão de adsorção de sódio (RAS) $=12,7$. Os teores mais elevados de alguns elementos, princialmente de cálcio, tanto no solo quanto na água de irrigação, contribuem para o desequilíbrio nutricional das plantas.

Considerando o uso de irrigação, os solos Nitossolo Háplico, Latossolo Vermelho-Amarelo, Latossolo Vermelho, Cambissolo Háplico e Argissolo Vermelho-Amarelo, localizados em áreas com relevo plano a suave ondulado apresentam limitações ligeiras a moderadas à agricultura mais intensiva, devido ao risco de erosão. Nessas áreas, recomendam-se práticas simples de conservação do solo, tais como, cultivo em nível, rotação de culturas, cultivos consorciados e manutenção da cobertura e da matéria orgânica do solo.

Os solos Nitossolo Háplico, Cambissolo Háplico e Argissolo Vermelho-Amarelo, em função da mineralogia (predominância de caulinitas), são facilmente compactados pelo tráfico de máquinas agrícolas e pisoteio de animais. Nessas áreas, além das práticas de manejo já citadas, recomenda-se o cultivo mínimo, plantio direto e a subsolagem periódica. Principalmente nas áreas de Latossolos, onde a vegetação predominante é a de Cerrado, é importante destacar que nesse ambiente a coleta de frutos nativos é uma atividade econômica também importante para a população local.
Nas áreas de ocorrência dos solos Cambissolo Háplico e Argissolo Vermelho-Amarelo, com relevo ondulado, há limitações moderadas ao risco de erosão e de impedimento à mecanização. Nessas áreas, além das práticas conservacionistas citadas anteriormente, recomenda-se a construção de terraços como prática de conservação do solo e da água. Nas áreas de relevo forte ondulado, ocorrem limitações fortes a muito fortes de risco de erosão e impedimento à mecanização, sendo mais apropriado o uso dessas áreas para pastagens e, ou preservação da fauna e flora silvestres.

Outra propriedade importante para o uso agrícola das terras é a consistência do solo. A consistência reflete as forças de coesão e de adesão das partículas sólidas em função da umidade, sendo influenciada pela textura, matéria orgânica e mineralogia do solo. De acordo com Resende et al. (2014), quanto maior o teor de argila do solo, maior a expressão das forças de coesão e adesão, e elevados teores de silte e areia muito fina favorecem o encrostamento da superfície.

A consistência é geralmente determinada com o solo seco, úmido e molhado. A consistência do solo seco e a consistência do solo úmido podem ser verificadas pela compressão de um torrão ou agregado entre os dedos: seco, estima-se a dureza e úmido, estima-se a friabilidade. A consistência do solo molhado é avaliada pelo manuseio de uma amostra de solo até atingir a saturação, estimando-se a plasticidade e pegajosidade (Lepsch, 2011). No município de Montes Claros - MG, os solos Argissolo Vermelho-Amarelo, Nitossolo Háplico e Cambissolo Háplico são menos friáveis que os Latossolos, ou seja, são mais duros quando secos e mais pegajosos e plásticos quando molhados.

O preparo do terreno para plantio, por exemplo, deve ser realizado quando o solo estiver na faixa de umidade correspondente à friabilidade, uma vez que nessa faixa apresenta baixa resistência ao destorroamento e menor susceptibilidade à compactação. De acordo com essa recomendação, os Latossolos, principalmente o Latossolo Vermelho-Amarelo, podem ser trabalhados em uma faixa de umidade mais ampla.

Ainda em relação as propriedades físicas do solo, as estradas não pavimentadas, que ocorrem nas áreas de Latossolo Vermelho-Amarelo, praticamente não são lamacentas no período chuvoso e não apresentam grandes quantidades de poeira (partículas finas de solo em suspensão) no período seco. Já as estradas nas áreas de Argissolo Vermelho-Amarelo, Nitossolo Háplico e Cambissolo Háplico podem formar grandes quantidades de lama no período chuvoso e, no período seco, formar muita poeira, principalmente no Cambissolo Háplico que possui elevados teores de silte. 
Sampaio, R. A.; Fernandes, L. A.

Figura 11 - Atributos gerais e limitações de uso das principais ordens de solo do município de Montes Claros - MG.

\begin{tabular}{|c|c|c|c|c|c|c|}
\hline \multirow{2}{*}{ Atributos do solo e limitações de uso } & \multicolumn{6}{|c|}{ Solo ${ }^{(1)}$} \\
\hline & LVA & LV & PVA & NX & CX & RL \\
\hline \multicolumn{7}{|l|}{ Fertilidade natural } \\
\hline \multicolumn{7}{|l|}{ Baixa $^{(2)}$} \\
\hline \multicolumn{7}{|l|}{ Média a alta ${ }^{(3)}$} \\
\hline \multicolumn{7}{|l|}{ Profundidade efetiva (horizontes $A+B$ ) } \\
\hline \multicolumn{7}{|l|}{ Rasa $(<50 \mathrm{~cm})$} \\
\hline \multicolumn{7}{|l|}{ Pouco profundo $(50-100 \mathrm{~cm})$} \\
\hline \multicolumn{7}{|l|}{ Profunda a muito profunda $(>100 \mathrm{~cm})$} \\
\hline \multicolumn{7}{|l|}{ Friabilidade } \\
\hline \multicolumn{6}{|l|}{ Pouco friável } & \multirow{2}{*}{$\mathrm{NSE}^{(4)}$} \\
\hline Fiável & & & & & & \\
\hline
\end{tabular}

\section{Rochosidade}

Muito a extremamente rochosa (afloramentos de rocha)

\section{Declividade}

Plana a suave ondulada (declividade menor que 8\%)

Ondulada a forte ondulada (declividade de 8 a 45\%) ${ }^{(5)}$

Ondulada a escarpada (declividade maior que 8\%)

\section{Susceptibilidade à erosão}

\begin{tabular}{|l|l|l|l|l|l|l|}
\hline Ligeira & & & & & & \\
\hline Moderada & & & & & & \\
\hline Severa $^{(5)}$ & & & & & & \\
\hline Muito a extremamente severa & & & & & &
\end{tabular}

\section{Limitações ao uso agrícola (médio e alto nível tecnológico)}

Seca prolongada e ocorrência de veranicos

Alta probabilidade de compactação

Elevada susceptibilidade à erosão

Impedimento ligeiro à mecanização

Impedimento moderado à forte à mecanização

Impedimento muito forte à mecanização

(1) LVA: Latossolo Vermelho-Amarelo; LV: Latossolo Vermelho; PVA: Argissolo Vermelho-Amarelo; NX: Nitossolo Háplico; CX: Cambissolo Háplico; RL: Neossolo Litólico. (2) Algumas manchas de LV, PVA, NX e CX apresentam valores mais elevados de pH e de Ca+Mg quando desenvolvidos a partir de rochas calcárias. Em algumas machas desses solos, principalmente de PVA, os teores de K são elevados, em função da ocorrência de muscovita no material de origem. Algumas manchas de NX apresentam teores médios a altos de P. (3) Apesar de apresentarem acidez fraca ou neutra e elevada saturação por bases, os teores de P são baixos. (4) NSE: Não se enquadra em função da rochosidade. (5) Algumas manchas de NX ocorrem em relevo forte ondulado, com riscos severos de erosão. 
Aspectos geológicos e pedológicos dos solos do município de Montes Claros - MG

Figura 12 - Recomendações gerais de uso e manejo dos principais solos do município de Montes Claros - MG.

\begin{tabular}{|c|l|l|l|}
\hline Solo(1) & \multicolumn{1}{|c|}{ Uso Agrícola $^{(2)}$} & \multicolumn{1}{|c|}{ Práticas de manejo } & \multicolumn{1}{c|}{ Uso alternativo / convivência } \\
\hline LVA, LV & $\begin{array}{l}\text { Culturas anuais e pere- } \\
\text { nes; Pastagens; Silvicul- } \\
\text { tura. }\end{array}$ & $\begin{array}{l}\text { Correção da acidez e adubação; Constru- } \\
\text { ção de terraços; Preparo do solo e plan- } \\
\text { tio em nível; Manutenção da cobertura } \\
\text { do solo e da matéria orgânica. }\end{array}$ & $\begin{array}{l}\text { Extrativismo de frutos nativos do } \\
\text { Cerrado e plantas medicinais. }\end{array}$ \\
PVA, NX & $\begin{array}{l}\text { Culturas anuais e pere- } \\
\text { nes; Pastagens; Silvicul- } \\
\text { tura. }\end{array}$ & $\begin{array}{l}\text { Correção da acidez e adubação; Constru- } \\
\text { ção de terraços; Preparo do solo e plan- } \\
\text { tio em nível; Manutenção da cobertura } \\
\text { do solo e da matéria orgânica; Cultivo } \\
\text { mínimo; Plantio Direto; Subsolagem. }\end{array}$ & $\begin{array}{l}\text { Conservação da fauna e flora; Ex- } \\
\text { trativismos de plantas medicinais; } \\
\text { Apicultura. }\end{array}$ \\
\hline CX & $\begin{array}{l}\text { Pastagens plantadas e, } \\
\text { ou, nativas. }\end{array}$ & $\begin{array}{l}\text { Correção da acidez e adubação; Constru- } \\
\text { ção de terraços; Preparo do solo e plan- } \\
\text { tio em nível; Manutenção da cobertura } \\
\text { do solo e da matéria orgânica. }\end{array}$ & $\begin{array}{l}\text { Conservação da fauna e flora; } \\
\text { Extrativismo de frutos nativos do } \\
\text { cultura. }\end{array}$ \\
\hline RL & Não recomendadantas medicinais; Api- \\
\hline
\end{tabular}

(1) LVA: Latossolo Vermelho-Amarelo; LV: Latossolo Vermelho; PVA: Argissolo Vermelho-Amarelo; NX: Nitossolo Háplico; CX: Cambissolo Háplico; RL: Neossolo Litólico. (2) Não considerada a restrição do fator climático: seca prolongada e veranicos.

Os Neossolos Litólicos, devido à pouca profundidade efetiva do solo, afloramentos de rochas e declividade acentuada, apresentam riscos elevados de erosão e limitações muito fortes à mecanização. Essas áreas devem ser utilizadas para a preservação da fauna e flora silvestres e recreação. Nas áreas de ocorrência de Cambissolo Háplico e Neossolo Litólico em relevos forte ondulado e montanhoso, a vegetação nativa predominante é a transição Cerrado-Floresta Estacional e, ou Floresta Estacional, onde a diversidade e disponibilidade de frutos nativos são menores do que nas áreas de Cerrado. No entanto, além de frutos nativos, a coleta de plantas medicinais e apicultura, por exemplo, são alternativas econômicas para essas áreas, de modo a gerar renda e preservar os recursos naturais.

Embora as principais características e propriedades dos solos predominantes no município de Montes Claros, aqui descritas, constituam um importante ponto de referência para o adequado manejo da fertilidade do solo e da irrigação, tendo em vista o uso racional de corretivos da acidez do solo, de fertilizantes e da água, recomenda-se a análise química e física do solo da área a ser cultivada.

Por fim, o uso agrícola dos solos deve considerar o nível tecnológico e o conhecimento local dos agricultores, construídos ao longo do tempo, sobre o uso das terras e de convivência com as limitações e diversidades ambientais locais, e a preservação e aproveitamento dos recursos naturais (Fernandes et al., 2008).

Na Figura 11 são resumidos os principais atributos químicos e físicos dos solos e as limitações para o uso agrícola, enquanto, Na Figura 12, são apresentadas algumas recomendações gerais de uso e manejo dos principais solos do município de Montes Claros - MG.

\section{Conclusões}

No município de Montes Claros predominam solos profundos, com bom desenvolvimento pedológico, sendo que, quando sob influência de calcários, possuem maior fertilidade química. Todavia, mesmo aqueles formados sob a influência de metassiltitos / metargilitos, com baixa fertilidade química, possuem bons atributos para a agricultura. Para uma elevada e sustentável produtividade agrícola é necessário adotar um manejo que contemple a calagem em solos ácidos, inclusive tendo-se o cuidado de equilibrar a relação do magnésio com outros cátions, e a fertilização, principalmente com nitrogênio e fósforo. Para os solos de origem calcária, é importante o uso de adubos amoniacais para reduzir a alcalinidade e prevenir a deficiência de micronutrientes. Independentemente do material de origem do solo, é necessário a adoção de práticas de incremento de matéria orgânica e de conservação, proporcionando uma maior infiltração e armazenamento de água, de forma a atenuar o impacto do intenso déficit hídrico que ocorre na região.

\section{Agradecimentos}

Os autores agradecem ao Programa de Pós-Graduação em Produção Vegetal do Instituto de Ciências Agrárias da UFMG pelo apoio a realização deste trabalho, ao Dr. Danilo Augusto de Oliveira Naliato pela confecção dos mapas, ao técnico em audiovisual Jorge Luiz Pereira Alves pelas fotografias e aos professores Dr. Expedito José Ferreira e Dr. Igo Fernando Lepsch pela revisão do trabalho. 
Sampaio, R. A.; Fernandes, L. A.

\section{Referências}

Alvares C. A.; Stape, J. L.; Sentelhas, P. C.; de Moraes Goncalves, J. L.; Sparovek, G. 2013. Köppen's climate classification map for Brazil. Meteorologische Zeitschrift, 22:711-728. Doi: https://doi.org/10.1127/09412948/2013/0507.

Embrapa. 2018. Sistema Brasileiro de Classificação de Solos. 5. Ed. Embrapa-Solos. Rio de Janeiro, RJ. Disponível em: https://www.embrapa.br/en/solos/sibcs.

Chaves, M. L. de S. C.; Andrade, K. W. 2012. Geologia e recursos minerais da folha Bocaiúva SE.23- X-C-III: Estado de Minas Gerais. Belo Horizonte: CPRM. Disponível em: https://rigeo.cprm.gov.br/xmlui/bitstream/ handle/doc/11368/nota_explicativa.pdf? sequence $=1$ \&isAllowed $=\mathrm{y}$.

Chaves, M. L. de S. C.; Andrade, K. W. 2014a. Geologia e recursos minerais da folha Montes Claros SE.23-X-A-VI: Estado de Minas Gerais. Belo Horizonte: CPRM. Disponível em: https://rigeo.cprm.gov.br/ xmlui/bitstream/handle/doc/18279/relatorio_montes_claros.pdf?sequence $=3$ \&isAllowed $=y$.

Chaves, M. L. de S. C.; Andrade, K. W. 2014b. Projeto Norte de Minas folha Coração de Jesus (SE 23-X-A-V) Escala 1:100.000. Belo Horizonte, CODEMIG - Governo de Minas - UFMG - CPMTC. Disponível em: http://www.portalgeologia.com.br/index.php/mapa/.

Chaves, M. L. de S. C.; Andrade, K. W.; Benitez, L. 2011. Geologia integrada das folhas Jequitaí, Bocaiúva e Montes Claros (1:100.000), Norte de Minas Gerais. Geonomos, v.19, p. 1-7. Doi: file:///C:/Users/ Usuario/Downloads/11757-Article\%20Text-31072-1-10-20181207.pdf.

Chaves, M. L. de S. C.; Benitez, L. 2007. Projeto Norte de Minas: Folha Jequitaí (SE.23-X-C-II) Escala 1:100.000. Belo Horizonte, CPRM - UFMG. Disponível em: https://rigeo.cprm.gov.br/jspui/bitstream/ doc/10766/1/nota.pdf.

Duarte, R. F.; Santana, C. S.; Fernandes, L. A.; Silva, I. C. B.; Sampaio, R. A.; Frazao, L. A. 2015. Phosphorus availability from natural and soluble phosphate sources for irrigated corn production. African Journal of Agricultural Research, 10:3101-3106. Doi: https://www. researchgate.net/publication/281108115.

Fernandes, L. A.; Lopes, P. S. N.; Dangelo, S.; Dayrell, C. A.; Sampaio, R. A. 2008. Relação entre o conhecimento local, atributos químicos e físicos do solo e uso das terras. Revista Brasileira de Ciência do Solo, 32:13551365. Disponível em: https://www.rbcsjournal.org/wp-content/ uploads/articles xml/0100-0683-rbcs-S0100-06832008000300043/ 0100-0683-rbcs-S0100-06832008000300043.pdf.

IBGE. 2012. Manual técnico da vegetação brasileira. 2 ed. Editora IBGE. Rio de Janeiro, RJ. Disponível em: https://www.terrabrasilis. org.br/ecotecadigital/pdf/manual-tecnico-da-vegetacao-brasileira.pdf.

Jacomine, P. K. T. 1979. Levantamento exploratório - reconhecimento de solos do Norte de Minas Gerais. Embrapa/SNLCS - Sudene/DRN. Brasília, DF. Disponível em: file:///C:/Users/Usuario/Downloads/ CNPSBOL.TEC.6079.pdf.
Kuchenbecker, M.; Costa, R. D. 2014. Projeto Norte de Minas: Folha Capitão Enéas (SE.23-X-A-III). Escala 1:100.000. Belo Horizonte, CODEMIG - Governo de Minas - UFMG - CPMTC. Disponível em: http:// www.portalgeologia.com.br/index.php/mapa/.

Kuchenbecker, M; Batista, G. A. P.; Pereira, A. de S.; Pacheco, F. E. R. C.; Magalhães, M. G. de; Costa, R. D. 2014. Projeto Norte de Minas: Folha Brasília de Minas (SE.23-Y-D-IV). Escala 1:100.000. Belo Horizonte, CODEMIG - Governo de Minas - UFMG - CPMT. Disponível em: http:// www.portalgeologia.com.br/index.php/mapa/.

Lepsch, I. F. 2011. 19 Lições de pedologia. Editora Oficina de Textos. São Paulo, SP.

Matos, L. V. 2008. Conhecimentos na análise de ambientes: a pedologia e o saber local em comunidade quilombola do Norte de Minas Gerais. Universidade Federal de Viçosa, 167p. Dissertação de Mestrado. Disponível em: https://www.locus.ufv.br/bitstream/123456789/5400/1/ texto\%20completo.pdf.

Oliveira, C. V.; Ker, J. C.; Curi, N.; Duarte, M. N.; Fontes, L. E. F. 2001. Caracterização de concreções ferromanganosas de solos de calcário no norte do Estado de Minas Gerais. Revista Brasileira de Ciência do Solo, 25:65-574. Doi: https://doi.org/10.1590/S0100-06832001000300005.

Oliveira, J. B. de; Jacomine, P. K. T.; Camargo, M. N. 1992. Classes gerais de solos do Brasil: guia auxiliar para seu reconhecimento. Editora FUNEP. Jaboticabal, SP.

Resende, M.; Curi, N.; Resende, S.B.; Corrêa, G.F.; Ker, J.C. 2014. Pedologia: Base para distinção de ambientes. 6 Ed. Editora UFLA. Lavras, MG.

Ribeiro, A.C.; Guimarães, P. T. G.; Alvarez, V. V. H. 1999. Recomendações para o uso de corretivos e fertilizantes em Minas Gerais - 5 $\mathbf{a}$ aproximação. CFSEMG, Viçosa, MG. Disponível em: https://edisciplinas.usp. br/pluginfile.php/5330754/mod resource/content/1/5\%C2\%AA\%20 -\%20Aproxima $\%$ C3\%A7\%C3\%A30\%20-20Recomenda $\%$ C3\%A7\%C3\%A3o\%20para\%20o\%20uso\%20de\%20corretivos\%20e\%20fertilizantes\%20em\%20Minas\%20Gerais.pdf.

Teixeira, P. C.; Donagemma, G. K.; Fontana, A.; Teixeira, W. G. 2017. Manual de métodos de análise de solo. 3. ed. Editora Embrapa. Brasília, DF. Disponível em: https://www.researchgate.net/publication/267038200_ Manual de Metodos_de_Analise_de_Solo_2a_Edicao.

Valadares, R. V.; Valadares, S. V.; Fernandes, L. A.; Sampaio, R. A. 2014. Teores de nutrientes no solo e nutrição mineral do milho em áreas irrigadas com água calcária. Revista Caatinga, 27:69-176. Doi: https://periodicos.ufersa.edu.br/index.php/caatinga/article/view/2736/pdf 151.

Valadão, R. C.; Oliveira, C. V. de; Ker, J. C. 2008. Compartimentação regional do relevo e cobertura pedológica do centro-norte de Minas Gerais. Geografias, 4:93-100. Doi: https://periodicos.ufmg.br/index. php/geografias/article/view/13256/10488. 